\title{
CTSTM immune cell SR for serum free culture and expansion of human $T$ cells
}

\author{
Grethe Okern ${ }^{1}$, Angel Varela-Rohena ${ }^{2}$, Sandra Kuligowski ${ }^{2}$, Brian Newsom³ ${ }^{3}$ Tanja Aarvak ${ }^{1 *}$ \\ From 30th Annual Meeting and Associated Programs of the Society for Immunotherapy of Cancer (SITC \\ 2015) \\ National Harbor, MD, USA. 4-8 November 2015
}

\section{Background}

The manufacture of a majority of clinical $\mathrm{T}$ cell products for immunotherapy applications requires in vitro $\mathrm{T}$ cell culture and expansion. Commercialization of $\mathrm{T}$ cell manufacturing processes requires reagents that meet regulatory guidelines and ultimately help reduce manufacturing cost of goods. A key component in many $\mathrm{T}$ cell culture protocols is human serum, which is expensive and requires extensive testing prior to use for the manufacture of cGMP-compliant $\mathrm{T}$ cell therapies. To this end, we have developed a xeno-free serum replacement, CTS ${ }^{\mathrm{TM}}$ Immune Cell SR, with defined components that can be used in combination with multiple cell culture media to support in vitro expansion of functionally intact $\mathrm{T}$ cells.

\section{Results}

T cells activated and expanded with Dynabeads ${ }^{\circledR}$ CD3/ CD28 CTS $^{\mathrm{TM}}$ and cultured in CTS ${ }^{\mathrm{TM}}$ OpTmizer $^{\mathrm{TM}} \mathrm{T}$ cell Expansion SFM, X-Vivo ${ }^{\mathrm{TM}} 15$, or CTSTMAIM-V ${ }^{\circledR}$ supplemented with pooled human serum or serum free CTS ${ }^{\mathrm{TM}}$ Immune Cell SR showed similar growth kinetics, total fold expansion and transduction efficiency after 2 weeks in culture. Numbers of $\mathrm{CD} 4^{+}$and $\mathrm{CD} 8^{+} \mathrm{T}$ cells were comparable in cultures expanded with media containing human serum or CTS ${ }^{\mathrm{TM}}$ Immune Cell SR. T cells demonstrated efficacy when infused in an in vivo leukemia mouse model. $T$ cell engraftment and leukemia control were similar between mice treated with $\mathrm{T}$ cells grown in media containing human serum or CTS ${ }^{\mathrm{TM}}$ Immune Cell SR.

\section{Conclusions}

These studies demonstrate that human serum may be replaced by a xeno-free formulation in combination

${ }^{1}$ Thermo Fisher Scientific, Oslo Norway

Full list of author information is available at the end of the article with several commonly used $\mathrm{T}$ cell culture media to support in vitro expansion and lentiviral transduction of polyclonal $\mathrm{T}$ cells. Culturing $\mathrm{T}$ cells in CTS ${ }^{\mathrm{TM}}$ Immune Cell SR facilitates a favorable culture profile and immune function. Serum free CTSTM Immune Cell SR contains only fully tested human-derived or human recombinant proteins which facilitates supply security for large-scale production of clinical and commercial therapies.

\section{Authors' details}

${ }^{1}$ Thermo Fisher Scientific, Oslo Norway. ${ }^{2}$ Thermo Fisher Scientific, Grand Island, NY, USA. ${ }^{3}$ Thermo Fisher Scientific, Frederick, MD, USA.

Published: 4 November 2015

doi:10.1186/2051-1426-3-S2-P1

Cite this article as: Okern et al:: CTS ${ }^{\mathrm{TM}}{ }^{\mathrm{TM}}$ immune cell SR for serum free culture and expansion of human T cells. Journal for ImmunoTherapy of Cancer 2015 3(Suppl 2):P1.

Submit your next manuscript to BioMed Central and take full advantage of:

- Convenient online submission

- Thorough peer review

- No space constraints or color figure charges

- Immediate publication on acceptance

- Inclusion in PubMed, CAS, Scopus and Google Scholar

- Research which is freely available for redistribution 